\title{
Removal of Chromium(VI) from Aqueous Solution Using Persimmon Tannin Gel and Subsequent Recovery as Chromium(III)
}

\author{
Tomonobu Hatano, Takehiko Tsuruta* \\ Department of Life and Environmental Science, Hachinohe Institute of Technology, Hachinohe, Japan \\ Email: ^tsuruta@hi-tech.ac.jp
}

How to cite this paper: Hatano, T. and Tsuruta, T. (2018) Removal of Chromium(VI) from Aqueous Solution Using Persimmon Tannin Gel and Subsequent Recovery as Chromium(III). International Journal of Geosciences, 9, 593-605. https://doi.org/10.4236/ijg.2018.910035

Received: August 24, 2018

Accepted: October 8, 2018

Published: October 11, 2018

Copyright (c) 2018 by authors and Scientific Research Publishing Inc. This work is licensed under the Creative Commons Attribution International License (CC BY 4.0).

http://creativecommons.org/licenses/by/4.0/

\begin{abstract}
This study herein was investigated the removal of chromium(VI) from an aqueous solution using persimmon tannin gel and its subsequent recovery as chromium(III). At $\mathrm{pH} 2, \mathrm{Cr}(\mathrm{VI})$ was effectively adsorbed ( $80 \%$ adsorption) and $<20 \%$ of this $\mathrm{Cr}(\mathrm{VI})$ was reduced to $\mathrm{Cr}(\mathrm{III})$ in the solution. More specifically, all adsorbed $\mathrm{Cr}(\mathrm{VI})$ from a $50 \mathrm{ppm}$ solution was reduced to $\mathrm{Cr}(\mathrm{III})$ on the persimmon gel within $10 \mathrm{~min}$. Although desorption of the $\mathrm{Cr}$ (III) species was challenging at $30^{\circ} \mathrm{C}$, it was increased upon increasing the temperature and was quantitatively desorbed in the presence of $1 \mathrm{M}$ hydrochloric acid under reflux. In addition, although the quantity of retained $\mathrm{Cr}(\mathrm{VI})$ on the tannin gel increased upon increasing the chromium concentration of the original aqueous solution, all the desorbed chromium was successfully reduced to $\mathrm{Cr}(\mathrm{III})$. Finally, $\mathrm{Cr}(\mathrm{VI})$ removal and recovery as $\mathrm{Cr}(\mathrm{III})$ was repeated effectively 8 times using the same persimmon tannin gel sample, thus demonstrating the recyclability of this system.
\end{abstract}

\section{Keywords}

Cr(VI) Removal, Cr(III) Recovery, Persimmon Tannin Gel, Reduction, Adsorption, Desorption

\section{Introduction}

Chromium is commonly employed in the textile, leather tanning, electroplating, metal finishing, wood treatment, corrosion control, oxidation, and anodizing industries [1]. This can be an issue, as the absorption of high levels of chromium by the body can generate serious health issues, with a concentration of $100 \mu \mathrm{g} / \mathrm{g}$ body wt. being potentially lethal [2]. Currently, the main processes for the eli- 
mination of chromium are adsorption, reverse osmosis, and chemical reactions that involve reduction and precipitation [1]. Among these processes, adsorption is a feasible method for removing traces of chromium from wastewater [1] and many adsorbents have been examined for this purpose [2] [3].

In this context, adsorption is the most effective and widely used technique for the removal of toxic heavy metals from wastewater [4]. Although activated carbon has been commonly used for this purpose, it is limited by its high cost and limited availability [1]. To address these issues, various low-cost substances, such as fly ash [5], wood charcoal [6], bituminous coal [7], bagasse and coconut juice [8], rice husk carbon [9], peat [10], red mud [11], used black tea leaves [12], activated carbon from industrial sugar waste [13], and sugarcane bagasse [14] have been examined.

It was previously demonstrated that microorganisms can remove many toxic and useful metals, such as lithium [15], uranium [16], thorium [17], rare earth metals [18], and gold [19] from aqueous solutions. Additionally, immobilized persimmon tannin gel removes gold(III) from a hydrogen tetrachloroaurate(III) solution [20]. Although microorganisms can remove small amounts of chromium from a chromium(VI) solution, the quantities of chromium removed using persimmon tannin gel are significantly greater than those removed using microbial cells [21]. The effects of $\mathrm{pH}, \mathrm{Cr}(\mathrm{VI})$ concentration, quantities of cell, and process time on the removal of $\mathrm{Cr}(\mathrm{VI})$ have also been reported [22]. However, to date, the recovery of chromium from adsorbed $\mathrm{Cr}$ in persimmon gel has not been examined. Thus, It was herein reported the removal of $\mathrm{Cr}(\mathrm{VI})$ from an aqueous solution following reduction to $\mathrm{Cr}$ (III) and effect of temperature on desorption of chromium from adsorbed $\mathrm{Cr}(\mathrm{VI})$ using persimmon tannin gel; its subsequent recovery as $\mathrm{Cr}(\mathrm{III})$; and recycling removal-desorption of $\mathrm{Cr}$.

\section{Material and Methods}

\subsection{Immobilization of Persimmon Gel}

Commercially available kakishibu (an extract naturally fermented from the juice of un ripe persimmon fruit, tannin content, 4.0\%) was immobilized as follows. One part of formalin (35\% aqueous formaldehyde solution) was mixed with four parts of the above kakishibu solution. After $2 \mathrm{~h}$, a dark red homogeneous gel was obtained. This gel was then crushed into small particles (diameter $150-300 \mu \mathrm{m}$ ) and washed thoroughly using deionized water prior to use in the $\mathrm{Cr}(\mathrm{VI})$ removal experiments.

\subsection{Adsorption and Desorption of Chromium from a Chromium(VI) Solution Using Persimmon Gel}

An aqueous solution of $\mathrm{Cr}(\mathrm{VI})$ in the form of $\mathrm{K}_{2} \mathrm{Cr}_{2} \mathrm{O}_{7}(10 \mathrm{~mL}, 50 \mathrm{ppm})$ at $\mathrm{pH}$ 2.0 (adjusted using $0.1 \mathrm{M} \mathrm{HCl}$ ) was passed through a column of persimmon gel (diameter $8 \mathrm{~mm}$; bed volume, $19.3 \mathrm{~mL}$ ). Desorption was then attempted under both acidic and basic conditions. Under acidic conditions, desorption was car- 
ried out by passing a $0.1 \mathrm{M} \mathrm{HCl}$ solution $(600 \mathrm{~mL})$ followed by a $1 \mathrm{M} \mathrm{HCl}$ solution $(400 \mathrm{~mL})$ through the column. In contrast under basic conditions, the solutions of $0.1 \mathrm{M} \mathrm{Na}_{2} \mathrm{CO}_{3}(300 \mathrm{~mL}), 1 \mathrm{M} \mathrm{Na}_{2} \mathrm{CO}_{3}(700 \mathrm{~mL})$, and $0.1 \mathrm{M} \mathrm{NaOH}$ $(300 \mathrm{~mL})$ were passed through the column. As the persimmon gel was soluble in $1 \mathrm{M} \mathrm{NaOH}$, this solution was not employed during the desorption experiments.

The quantity of $\mathrm{Cr}(\mathrm{VI})$ removed by the persimmon gel was then determined using the previously reported diphenyl carbazide method [23] and measuring the absorbance of the solution at $540 \mathrm{~nm}$ using a UV-Vis spectrophotometer (U-1800, Hitachi). Finally, the quantities of removed total chromium were determined by atomic absorption spectrometry (AA-6300, Shimadzu, Kyoto, Japan).

\subsection{Effect of Temperature on the Desorption of Chromium from Persimmon Gel}

A sample of persimmon gel (31.5 $\mathrm{mg}$, dry wt. basis) was added to a solution of potassium dichromate(VI) $(100 \mathrm{~mL})$ containing $50.0 \mathrm{ppm} \mathrm{Cr}(\mathrm{VI})$ and stirred for $1 \mathrm{~h}$ at $30^{\circ} \mathrm{C}$. The gels were then collected by filtration through a membrane filter (pore size $0.2 \mu \mathrm{m}$ ). For each experiment, the amount of adsorbed $\mathrm{Cr}(\mathrm{VI})$ was $86.9 \% \pm 0.2 \%$ and the amount of reduced $\mathrm{Cr}$ (III) in the solution was $11.8 \% \pm$ $0.4 \%$ based on the original $\mathrm{Cr}(\mathrm{VI})$ solution. The recovered gels were then added to a $1 \mathrm{M} \mathrm{HCl}$ solution $(100 \mathrm{~mL})$ and stirred for $1 \mathrm{~h}$ at the desired temperature (i.e., between $30^{\circ} \mathrm{C}$ and reflux. Finally, the quantities of removed $\mathrm{Cr}(\mathrm{VI})$ and total chromium in the filtrate were quantified using the above-mentioned method.

\subsection{Variations in Chromium(VI) Removal and Chromium Oxidation State with Time}

A sample of the adsorbent (15 mg, dry wt. basis) was suspended in a solution of potassium dichromate(VI) $(10 \mathrm{~mL})$ containing $50 \mathrm{ppm}(1.0 \mathrm{mM}) \mathrm{Cr}(\mathrm{VI})$ at $30^{\circ} \mathrm{C}$ for the desired time between $5 \mathrm{~min}$ and $24 \mathrm{~h}$. After the appropriate time, the quantities of removed $\mathrm{Cr}(\mathrm{VI})$ and total chromium in the filtrate were quantified using the above-mentioned method.

The oxidation state of the chromium species adsorbed on the persimmon gel was then investigated using X-ray absorption fine structure (XAFS) spectroscopy. The X-ray absorption fine spectra were collected at the BL14B2 beamline at the Spring-8 facility in Hyougo, Japan. All measurements were conducted at the $\mathrm{Cr} \mathrm{K}$-edge and data were collected in transmission and fluorescence modes for the standard and chromium-adsorbed samples, respectively, between 5660 and $7000 \mathrm{eV}$. The standard solutions, employed herein were aqueous solutions of $\mathrm{Cr}(\mathrm{VI})$ in the form of $\mathrm{K}_{2} \mathrm{Cr}_{2} \mathrm{O}_{7}(2500 \mathrm{ppm})$ and $\mathrm{Cr}(\mathrm{III})$ in the form of $\mathrm{Cr}\left(\mathrm{NO}_{3}\right)_{3}$ (5000 ppm). The chromium-adsorbed gel samples were collected by filtration through a membrane filter (pore size $0.2 \mu \mathrm{m}$ ) as described above for determination of chromium removal from the potassium dichromate(VI) solution by persimmon gel. 


\subsection{Effect of Chromium(VI) Concentration on the Removal and Oxidation State of Chromium in Persimmon Gel}

A sample of the adsorbent ( $15 \mathrm{mg}$, dry wt. basis) was suspended in a solution ( $\mathrm{pH}$ 2.00) containing the desired $\mathrm{Cr}(\mathrm{VI})$ concentration (i.e., $50-1000 \mathrm{ppm}$, $10 \mathrm{~mL}$ ) for $1 \mathrm{~h}$ at $30^{\circ} \mathrm{C}$. The quantities of removed $\mathrm{Cr}(\mathrm{VI})$ and total chromium in the filtrate were determined as described previously.

The oxidation state of the chromium adsorbed on the persimmon gel was then determined by X-ray absorption fine structure XAFS. These X-ray absorption fine spectra were collected at the BL9A beam line at the High Energy Accelerator Research Organization (KEK) in Tsukuba, Ibaraki, Japan, and measurements were carried out as described above but with an energy range of $5500-7100 \mathrm{eV}$.

\subsection{Recycling of the Gel Adsorbent and Recovery of Chromium as Chromium(III)}

An aqueous solution $(1 \mathrm{~L})$ containing $10 \mathrm{ppm} \mathrm{Cr}(\mathrm{VI})(190 \mu \mathrm{M})$ at $\mathrm{pH} 2.00$ was passed through a column (bed volume, $3.8 \mathrm{~mL}$ ) of persimmon gel $(202 \mathrm{mg}$, dry wt. basis) at a space velocity of $15.8 \mathrm{~h}^{-1}$. The chromium-adsorbed gels sample was then heated in $1 \mathrm{M} \mathrm{HCl}(100 \mathrm{~mL})$ at reflux for $1 \mathrm{~h}$ using a batch system. Following the successful desorption of chromium from the gel, this adsorption-desorption cycles was repeated 8 times ( 9 cycles in total) to confirm the possibility of recycling of this system. The quantities of $\mathrm{Cr}(\mathrm{VI})$ and total chromium in the solution were then determined quantified using the above-mentioned method.

\section{Results and Discussion}

\subsection{Chromium Adsorption/Desorption from a Chromium(VI) Solution Using Persimmon Gel}

We initially investigated the extent of chromium adsorption/desorption from a $\mathrm{Cr}(\mathrm{VI})$ solution using persimmon gel. As previously reported, the amount of chromium removed from solution using persimmon gel was strongly affected by the $\mathrm{pH}$ of the solution [21]. More specifically, we found that a $\mathrm{pH}$ of $1-2$ was optimal for our studies, as this $\mathrm{pH}$ resulted in the quantitative removal of $\mathrm{Cr}(\mathrm{VI})$ from solution, and any further increase in $\mathrm{pH}$ resulted in decreased adsorption [21]. In addition, the quantity of total chromium removed was maximised at $\mathrm{pH}$ 2 [21]. We therefore examined the adsorption of chromium at $\mathrm{pH} 2$, while the desorption of chromium from the persimmon gel column was examined using both acidic and basic conditions. As indicated in Figure 1 and Figure 2, the majority of $\mathrm{Cr}(\mathrm{VI})$ present in the solution was successfully adsorbed on the persimmon gel column (86.8\% for a $49.1 \mathrm{ppm} \mathrm{Cr}(\mathrm{VI})$ solution and $86.5 \%$ for 54.3 ppm $\mathrm{Cr}(\mathrm{VI})$ solution), and a percentage of this $\mathrm{Cr}(\mathrm{VI})$ was reduced to $\mathrm{Cr}(\mathrm{III})$ in solution (i.e., $13.2 \%$ and $13.5 \%$ respectively). Furthermore, $\mathrm{Cr}$ (III) was not adsorbed under these conditions [21]. We also found that relatively small quantities of chromium were desorbed under acidic conditions (16.0\%) using $0.1 \mathrm{M}$ 


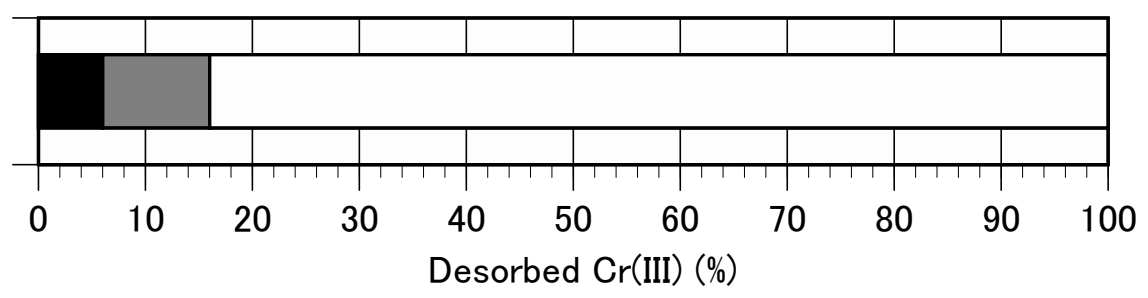

Figure 1. Desorption of chromium from persimmon gel using dilute hydrochloric acid. Black; Desorbed Cr(III) by $0.1 \mathrm{MHCl}$, Gray; Desorbed Cr(III) by $0.1 \mathrm{M} \mathrm{HCl}$, White; Undesorbed $\mathrm{Cr}$.

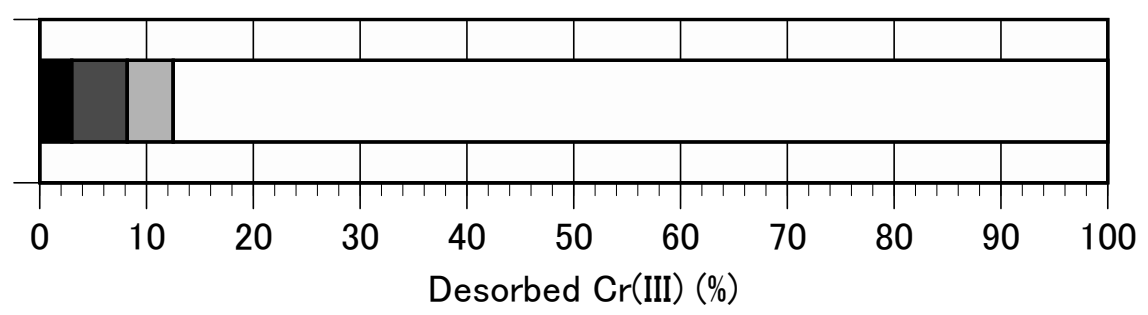

Figure 2. Desorption of chromium from persimmon gel using dilute sodium carbonate and sodium hydroxide solution. Black; Desorbed $\mathrm{Cr}$ (III) by $0.1 \mathrm{M} \mathrm{Na}_{2} \mathrm{CO}_{3}$, Dark gray; Desorbed Cr(III) by $1 \mathrm{M} \mathrm{Na}_{2} \mathrm{CO}_{3}$, Light gray; Desorbed $\mathrm{Cr}(\mathrm{III})$ by $0.1 \mathrm{M} \mathrm{NaOH}$, White; Undesorbed Cr.

and $1 \mathrm{M} \mathrm{HCl}$ solutions (Figure 1), and under basic conditions (12.5\%) using $0.1 \mathrm{M}$, $1 \mathrm{M} \mathrm{Na}_{2} \mathrm{CO}_{3}$ solutions or $0.1 \mathrm{M} \mathrm{NaOH}$ solution (Figure 2) at $30^{\circ} \mathrm{C}$. Moreover, we found that $100 \%$ of the desorbed chromium had been reduced to $\mathrm{Cr}$ (III).

\subsection{Effect of Temperature on the Desorption of Chromium from Persimmon Gel}

As described above, the quantity of desorbed chromium was rather low at $30^{\circ} \mathrm{C}$ and slightly greater quantities of chromium were desorbed under acidic conditions compared to under basic conditions. Thus, we moved on to examine the effect of temperature on chromium desorption under acidic conditions. As shown in Figure 3(a), the degree of chromium removal increased significantly with increasing temperature, and the majority of adsorbed chromium (i.e., 99.1\%) was successfully desorbed under reflux conditions. Furthermore, all adsorbed $\mathrm{Cr}(\mathrm{VI})$ was reduced to $\mathrm{Cr}(\mathrm{III})$.

The relationship between the reciprocal of temperature and the natural logarithm of the equilibrium constant is shown in Figure 3(b). As indicated from this plot, the desorption of adsorbed chromium from persimmon gel using hydrochloric acid obeys the Van't Hoff equation,

$$
\ln K=-\Delta H^{0} / R T+\Delta S^{0} / R
$$

where $K$ is the equilibrium constant (the ratio of desorbed/residual chromium), $\Delta H^{\oplus}$ is the enthalpy change $\left(\mathrm{J} \cdot \mathrm{mol}^{-1}\right), R$ is the gas constant $\left(8.314 \mathrm{~J} \cdot \mathrm{K}^{-1} \cdot \mathrm{mol}^{-1}\right)$, $T$ is the temperature $(\mathrm{K})$, and $\Delta S^{0}$ is the entropy change $\left(\mathrm{kJ} \cdot \mathrm{K}^{-1} \cdot \mathrm{mol}^{-1}\right)$ [24]. The enthalpy change was therefore estimated from the slope of the line to be 


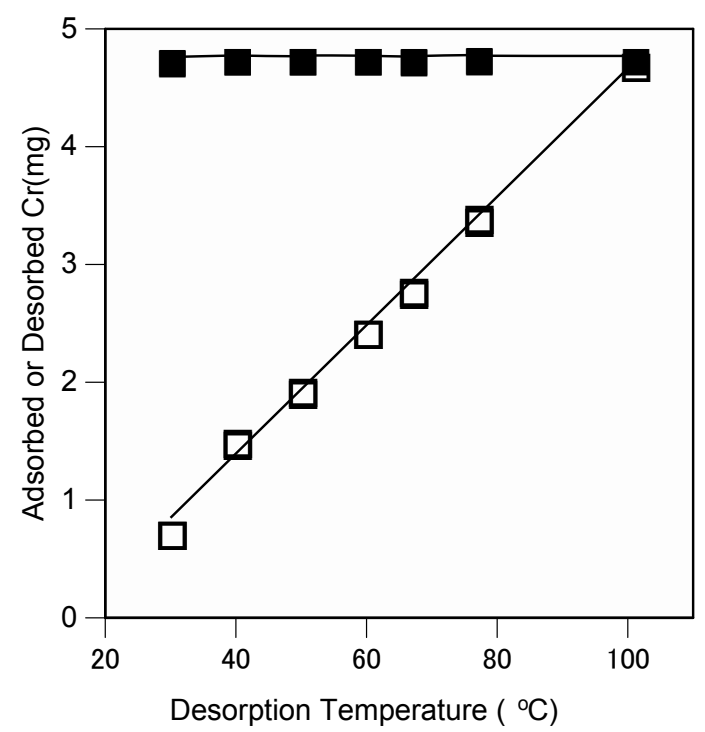

(a)

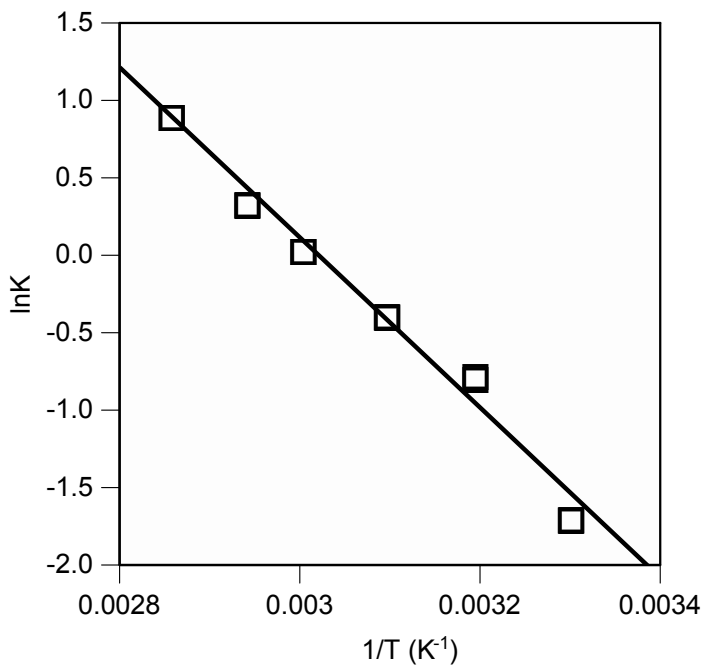

(b)

Figure 3. Effect of temperature on the desorption of chromium from persimmon gel containing adsorbed $\mathrm{Cr}(\mathrm{VI})$. Closed; $\mathrm{Cr}$ (adsorbed (mg)), Opened; $\mathrm{Cr}$ (desorbed (mg)).

$45.6 \mathrm{~kJ} \cdot \mathrm{mol}^{-1}$, which indicates that the desorption of chromium using dilute hydrochloric acid was an endothermic reaction. Furthermore, the entropy change was estimated to be $0.137 \mathrm{~kJ} \cdot \mathrm{K}^{-1} \cdot \mathrm{mol}^{-1}$. Moreover, as all desorbed chromium was in the form of $\mathrm{Cr}(\mathrm{III})$, it was clear that reduction had taken place on the persimmon gel prior to desorption.

\subsection{Effect of Time on Chromium(VI) Removal from Solution Using Persimmon Gel and on the Chromium Oxidation State}

The effect of time on both the chromium oxidation state and on $\mathrm{Cr}(\mathrm{VI})$ removal from solution using persimmon gel were then examined. As shown in Figure 4 (a), the removal of $\mathrm{Cr}(\mathrm{VI})$ was rapid with equilibrium being reached within 10 min when a sample of the adsorbent was suspended in the potassium dich- 
romate (VI) solution at $30^{\circ} \mathrm{C}$. Indeed, $\sim 90 \%$ of $\mathrm{Cr}(\mathrm{VI})$ was absorbed by the persimmon gel, with $10 \%$ of that being reduced to $\mathrm{Cr}(\mathrm{III})$ in solution.

As $\mathrm{Cr}(\mathrm{III})$ is not adsorbed by persimmon gel below $\mathrm{pH} 2$ [21], it was clear that all chromium adsorption observed herein was in the form of $\mathrm{Cr}(\mathrm{VI})$. Therefore, to confirm the variation in chromium oxidation state with time, the adsorbed chromium was analyzed by XAFS. The $\mathrm{Cr} \mathrm{K} \mathrm{X}$-ray absorption edges were measured for $\mathrm{Cr}(\mathrm{VI})$ in a $\mathrm{K}_{2} \mathrm{Cr}_{2} \mathrm{O}_{7}$ standard and for $\mathrm{Cr}(\mathrm{III})$ in a $\mathrm{Cr}\left(\mathrm{NO}_{3}\right)_{3}$ standard, where the presence of a sharp pre-edge peak at $5992 \mathrm{eV}$ corresponds to $\mathrm{Cr}(\mathrm{VI})$ and a broad signal at $\sim 6008 \mathrm{eV}$ corresponds to $\mathrm{Cr}$ (III). However, as shown in Figure 4(b), no signal at $5992 \mathrm{eV}$ was observed in the XAFS spectrum after10 min,

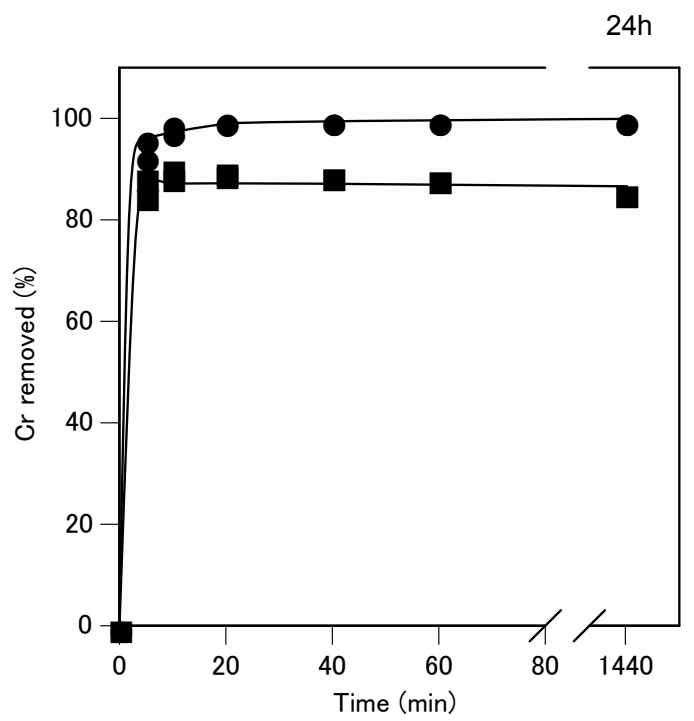

(a)

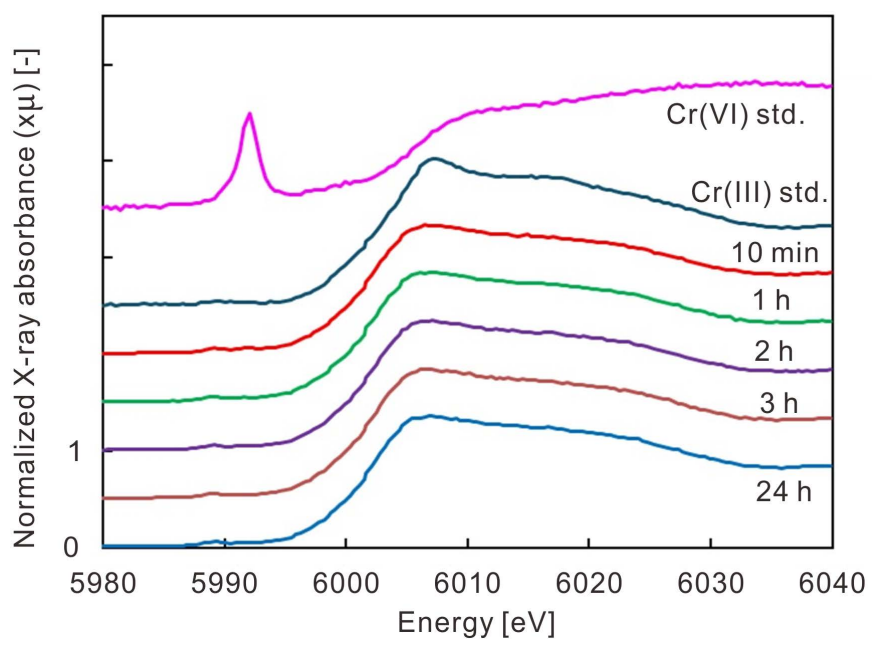

(b)

Figure 4. Effect of time on the removal of chromium from the potassium dichromate (VI) solution using the persimmon gel absorbent. (a) Removal of $\mathrm{Cr}(\mathrm{VI})$ with time. (b) Variation in the XAFS spectra with time. A sample of the adsorbent (15 mg, dry wt. basis) was suspended in the potassium dichromate $(\mathrm{VI})$ solution $(10 \mathrm{~mL})$ at $30^{\circ} \mathrm{C}$. Circles; removed $\mathrm{Cr}(\mathrm{VI})$, squares; removed chromium (total). 
with the presence of a broad signal at $\sim 6008 \mathrm{eV}$ indicating that all adsorbed $\mathrm{Cr}(\mathrm{VI})$ had been reduced to $\mathrm{Cr}(\mathrm{III})$ within this time.

\subsection{Effect of Chromium(VI) Concentration on the Removal and Oxidation State of Chromium in Persimmon Gel}

The effect of the $\mathrm{Cr}(\mathrm{VI})$ concentration on both the removal of chromium and on the oxidation state of chromium in persimmon gel was then examined. As shown in Figure 5(a), the percentage of $\mathrm{Cr}(\mathrm{VI})$ removal from the aqueous solution was quantitative at initial $\mathrm{Cr}(\mathrm{VI})$ concentrations $<400 \mathrm{ppm}(7.7 \mathrm{mM})$. However, above $400 \mathrm{ppm}$, the degree of $\mathrm{Cr}(\mathrm{VI})$ and total chromium removal decreased at higher initial chromium concentrations. Furthermore, the quantity of $\mathrm{Cr}(\mathrm{VI})$ and total chromium removed ( $\mu \mathrm{mol}$ chromium/g dry wt. adsorbents) increased linearly upon increasing the concentration of chromium in the aqueous solution up to $\sim 400 \mathrm{ppm}$ (i.e. quantitative adsorption up to a maximaum concentration of $400 \mathrm{ppm}$ ), after which only very small increases were observed. For example, when the original chromium concentration was 1000 ppm, $7000 \mu \mathrm{mol}$ of $\mathrm{Cr}(\mathrm{VI})$ and $6000 \mu \mathrm{mol}$ of total chromium/g dry wt. adsorbents was removed (1,000 $\mu \mathrm{mol}$ of $\mathrm{Cr}(\mathrm{VI}) / \mathrm{g}$ dry wt. adsorbents was reduced to $\mathrm{Cr}(\mathrm{III})$ in solution), which correspond to approximately $55 \%$ and $45 \%$ of the $\mathrm{Cr}(\mathrm{VI})$ and total chromium present in the original solution, respectively.

The oxidation states of the adsorbed chromium in this experiment were also analysed by XAFS. As shown in Figure 5(b), no signal was observed at $5992 \mathrm{eV}$ after $1 \mathrm{~h}$ when an initial $\mathrm{Cr}(\mathrm{VI})$ concentration of $50 \mathrm{ppm}$ was employed, thereby indicating that the adsorbed $\mathrm{Cr}(\mathrm{VI})$ had been reduced quantitatively. However, upon increasing the original $\mathrm{Cr}(\mathrm{VI})$ concentration above $200 \mathrm{ppm}$, the intensity of this signal increased. As such, the ratio of $\mathrm{Cr}(\mathrm{VI})$ to $\mathrm{Cr}$ (III) could be calculated using their respective peak areas, as shown in Table 1. More specifically, $\sim 60 \%$ of $\mathrm{Cr}(\mathrm{VI})$ was reduced where an initial $\mathrm{Cr}(\mathrm{VI})$ concentration of 800 1000 ppm had been employed.

Furthermore, desorption of the adsorbed chromium from the persimmon gel was examined at initial $\mathrm{Cr}(\mathrm{VI})$ concentration between 200 and $1000 \mathrm{ppm}$. As shown in Figure 5(c), the majority of adsorbed chromium was successfully desorbed independent of the initial $\mathrm{Cr}(\mathrm{VI})$ concentration. In addition, all desorbed chromium was in the form of $\mathrm{Cr}(\mathrm{III})$, thus indicating that any remaining unreduced $\mathrm{Cr}(\mathrm{VI})$ adsorbed on the persimmon gel was reduced to $\mathrm{Cr}(\mathrm{III})$ during the desorption procedure.

\subsection{Recycling of Chromium(VI) Removal and Recovery as Chromium(III)}

To obtain an indication of the recyclability of this system, $\mathrm{Cr}(\mathrm{VI})$ adsorption and its subsequent desorption as $\mathrm{Cr}$ (III) was repeated over 9 cycles. As shown in Figure 6, using a $1 \mathrm{M} \mathrm{HCl}$ solution at reflux, quantitative $\mathrm{Cr}(\mathrm{VI})$ adsorption, reduction to $\mathrm{Cr}(\mathrm{III})$, and subsequent, $\mathrm{Cr}(\mathrm{III})$ desorption were observed. More specifically, after 8 cycles, $\mathrm{Cr}(\mathrm{VI})$ adsorption was quantitative, while reduction to 


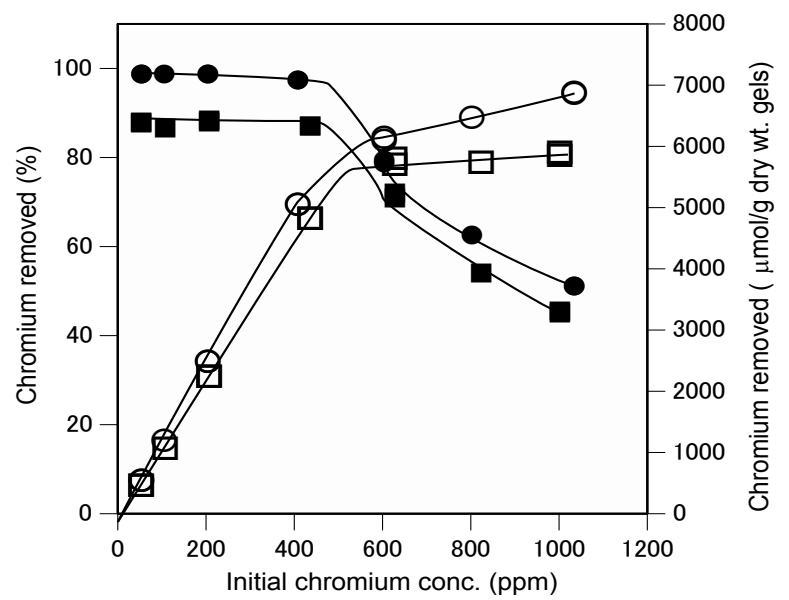

(a)

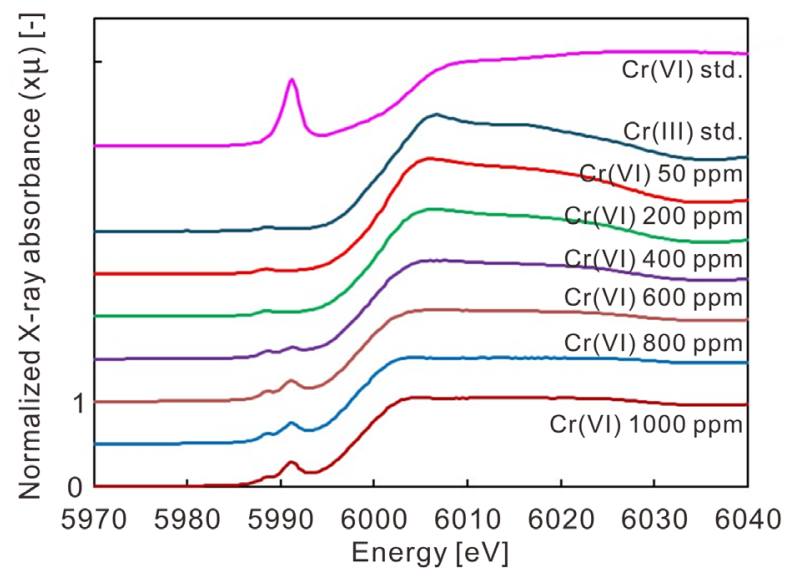

(b)

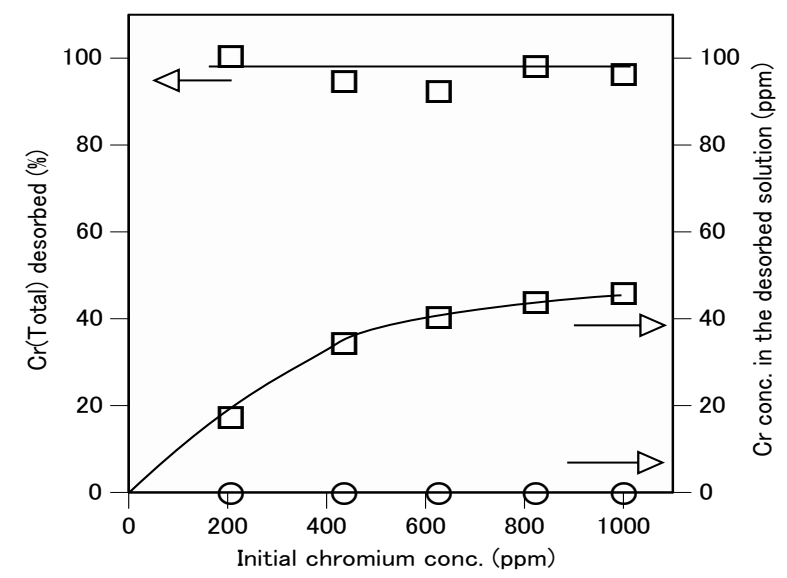

(c)

Figure 5. Effect of initial chromium concentration on $\mathrm{Cr}(\mathrm{VI})$ removal and on reduction to $\mathrm{Cr}$ (III) using the immobilized persimmon gel adsorbent. (a) Variation in chromium removal upon increasing the $\mathrm{Cr}(\mathrm{VI})$ concentration of the initial solution. Closed circles; removed $\mathrm{Cr}(\mathrm{VI})(\%)$, closed squares; removed $\mathrm{Cr}$ (total) (\%), opened circles; removed $\mathrm{Cr}(\mathrm{VI})$ (mol/g dry wt cells), opened squares removed $\mathrm{Cr}$ (total) (mol/g dry wt cells). (b) Variation in the XAFS spectra with initial Cr(VI) concentration. (c) Desorption of chromium as $\mathrm{Cr}(\mathrm{III})$ from a range of initial $\mathrm{Cr}(\mathrm{VI})$ concentrations. Circles; $\mathrm{Cr}(\mathrm{VI})$, squares; Cr(III). 
Table 1. Oxidation states of chromium adsorbed in the persimmon gel.

\begin{tabular}{ccc}
\hline Initial Cr(VI) conc. (ppm) & $\begin{array}{c}\text { Adsorbed unreduced } \\
\text { Cr(VI) (\%) in the gel }\end{array}$ & $\begin{array}{c}\text { Adsorbed reduced } \\
\mathrm{Cr}(\mathrm{III})(\%) \text { in the gel }\end{array}$ \\
\hline 50 & 0 & 100 \\
200 & 6 & 94 \\
400 & 14 & 86 \\
600 & 35 & 65 \\
800 & 43 & 57 \\
1000 & 42 & 58 \\
\hline
\end{tabular}

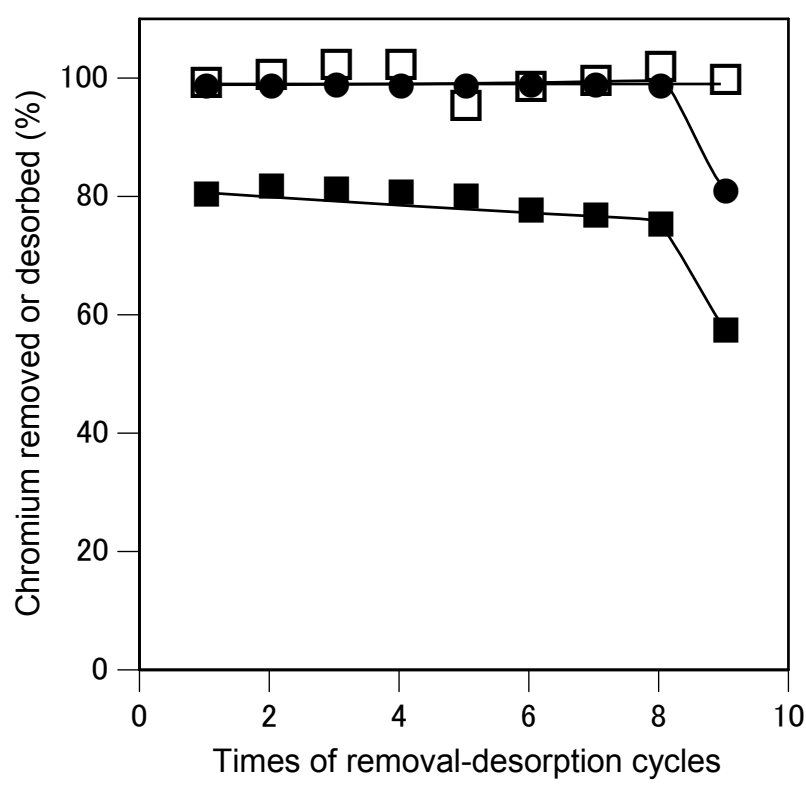

Figure 6. Recyclability of the system by examination of the degree of chromium removal and desorption using persimmon gel over a number of cycles. Circles; removed $\mathrm{Cr}(\mathrm{VI})$, closed squares; removed chromium (total), open squares; desorbed chromium (total).

Cr(III) remained at a relatively constant value of $\sim 80 \%$. However, during the $9^{\text {th }}$ cycle, the $\mathrm{Cr}(\mathrm{VI})$ adsorption decreased to $82 \%$, and reduction to $\mathrm{Cr}(\mathrm{III})$ decreased to $<60 \%$, although $\mathrm{Cr}(\mathrm{III})$ desorption was remained quantitative. We expect that this decrease in $\mathrm{Cr}(\mathrm{VI})$ adsorption was likely due to oxidation of the polyhydroxyphenyl group in the persimmon gel to give a polyquinone moiety. We could therefore conclude that under the conditions examined herein, persimmon gel could be successfully recycled 8 times for the adsorption/reduction/desorption of chromium species from aqueous solutions. It need to oxidized persimmon gel to reduce initial form for more recycle times.

\section{Conclusion}

It was herein investigated the removal of $\mathrm{Cr}(\mathrm{VI})$ from aqueous solutions using persimmon tannin gel and its subsequent recovery as $\mathrm{Cr}(\mathrm{III})$. This system proved particularly successful in this process, with the majority of $\mathrm{Cr}(\mathrm{VI})$ (i.e. $>80 \%$ ) being effectively adsorbed on the persimmon tannin gel at $\mathrm{pH} 2$ and 
$<20 \%$ of this $\mathrm{Cr}$ (VI) being successfully reduced to $\mathrm{Cr}$ (III). For example, with an initial chromium (VI) concentration of $50 \mathrm{ppm}$, quantitative reduction to $\mathrm{Cr}$ (III) was observed within $10 \mathrm{~min}$. In the context of $\mathrm{Cr}$ (III) desorption following reduction, quantitative desorption was achieved using a $1 \mathrm{M}$ hydrochloric acid solution at reflux. Furthermore, although the quantity of retained $\mathrm{Cr}(\mathrm{VI})$ on the persimmon gel increased upon increasing the original concentration of chromium in solution, all desorbed chromium was reduced to $\mathrm{Cr}$ (III). Moreover, we successfully demonstrated the recyclability of the persimmon gel sample through the successful removal of $\mathrm{Cr}(\mathrm{VI})$ and the subsequent recovery of $\mathrm{Cr}(\mathrm{III})$ over 8 cycles. It was therefore expected that our reported system for the removal of $\mathrm{Cr}(\mathrm{VI})$ using persimmon tannin gel and the subsequent recovery of $\mathrm{Cr}(\mathrm{III})$ by desorption using dilute hydrochloric acid at reflux will be applicable for the treatment of $\mathrm{Cr}(\mathrm{VI})$ containing wastewater samples.

\section{Acknowledgements}

We are grateful thanks to Dr. Hironori Ofuchi of the Industrial Application Division at the Japan Synchrotron Radiation Research Institute (JASRI) and to Assistant professor Dr. Hiroaki Nitani of the Institute of Materials Structure Science Synchrotron Radiation Science Division II (KEK) for XAFS measurements.

\section{Conflicts of Interest}

The authors declare no conflicts of interest regarding the publication of this paper.

\section{References}

[1] Mohamed, Al-M., Hesham, G.I. and Mohamed, M.A. (2008) Equilibrium and Kinetics of Chromium, Adsorption on Cement Kiln Dust. Proceedings of the World Congress on Engineering and Computer Science, 54-62. http://www.iaeng.org/publication/WCECS2008/WCECS2008_pp54-62.pdf

[2] Schneider, R.M., Cavalin, C.F., Barros, M.A.S.D. and Tavares, C.R.G. (2007) Adsorption of Chromium Ions in Activated Carbon. Chemical Engineering Journal, 132, 355-362. http://www.sciencedirect.com/science/article/pii/S1385894707000654 https://doi.org/10.1016/j.cej.2007.01.031

[3] Youssef, A.M., El-Nabarawy, T. and Samra, S.E. (2004) Sorption Properties of Chemically Activated Carbons. 1. Sorption of Cadmium(II) Ions. Colloids and Surfaces A: Physicochemical and Engineering Aspects, 235, 153-163. http://www.sciencedirect.com/science/article/pii/S0927775703007015

[4] Selvi, K., Pattabhi, S. and Kadirvelu, K. (2001) Removal of Cr(VI) from Aqueous Solution by Adsorption onto Activated Carbon. Bioresource Technology, 80, 87-89. http://www.sciencedirect.com/science/article/pii/S0960852401000682 https://doi.org/10.1016/S0960-8524(01)00068-2

[5] Grover, M. and Narayanswamy, M.S. (1982) Removal of Hexavalent Chromium by Adsorption on Fly Ash. Institution of Engineers. International Journal of Environmental Engineering, 63, 36-39. 
[6] Deepak, D. and Gupta, A.K. (1991) Hexavalent Chromium Removal from Wastewater. Indian Journal of Environmental Health, 33, 297-305.

[7] Kannan, N. and Vanangamudi, A. (1991) A Study on Removal of Cr(VI) by Adsorption Lignite Coal. International Journal of Environment and Pollution, 11, 241-245.

[8] Chand, S., Agarwal, V.K. and Pavankumar, C. (1994) Removal of Hexavalent Chromium from Wastewater by Adsorption. Indian Journal of Environmental Health, 36, 151-158.

[9] Srinivasan, K., Balasubramaniam, N. and Ramakrishna, T.V. (1988) Studies on Chromium Removal by Rice Husk Carbon. Indian Journal of Environmental Health, 30, 376-387.

https://www.researchgate.net/publication/279896854_Studies_on_Chromium_Rem oval_by_Rice_Husk_Carbon

[10] Brown, P.A. and Allen, S.J. (2000) Metal Removal from Wastewater Using Peat. Water Research, 34, 3907-3916.

http://www.sciencedirect.com/science/article/pii/S0043135400001524 https://doi.org/10.1016/S0043-1354(00)00152-4

[11] Gupta, V.K., Gupta, M. and Sharma, S. (2001) Process Development for the Removal of Lead and Chromium from Aqueous Solutions Using Red Mud-An Aluminum Industry Waste. Water Research, 35, 1125-1134.

http://www.sciencedirect.com/science/article/pii/S0043135400003894 https://doi.org/10.1016/S0043-1354(00)00389-4

[12] Hossain, M.A., Kumita, M., Michigami, Y. and Mori,S. (2005) Kinetics of Cr(VI) Adsorption on Used Black Tea Leaves. Journal of Chemical Engineering of Japan, 38, 402-406. https://doi.org/10.1252/jcej.38.402

[13] Fahim, N.F., Barsoum, B.N., Eid, A.E. and Khalil, M.S. (2006) Removal of Chromium(III) from Tannery Wastewater Using Activated Carbon from Sugar Industrial Waste. Journal of Hazardous Materials, 136, 303-309.

https://www.researchgate.net/profile/Narges_Fahim/publication/7330451_Removal _of_chromiumIII_from_tannery_wastewater_using_activated_carbon_from_sugar industrial_waste/links/0fcfd505a2d04ece6c000000.pdf https://doi.org/10.1016/j.jhazmat.2005.12.014

[14] Khan, N.A. and Mohamad, H. (2007) Investigation on the Removal of Chromium(VI) from Wastewater by Sugarcane Bagasse. Water and Wastewater Asia, 37-41.

[15] Tsuruta, T. (2005) Removal and Recovery of Lithium Using Various Microorganisms. Journal of Bioscience and Bioengineering, 100, 562-566.

http://www.sciencedirect.com/science/article/pii/S1389172305705107 https://doi.org/10.1263/jbb.100.562

[16] Tsuruta, T. (2002) Removal and Recovery of Uranyl Ion Using Various Microorganisms. Journal of Bioscience and Bioengineering, 94, 23-28.

http://www.sciencedirect.com/science/article/pii/S1389172302801116 https://doi.org/10.1016/S1389-1723(02)80111-6

[17] Tsuruta, T. (2003) Accumulation of Thorium Ion Using Various Microorganisms. The Journal of General and Applied Microbiology, 49, 215-218. https://doi.org/10.2323/jgam.49.215

[18] Tsuruta, T. (2006) Selective Accumulation of Light or Heavy Rare Earth Elements Using Gram-Positive Bacteria. Colloids and Surfaces B: Biointerfaces, 52, 117-122. http://www.sciencedirect.com/science/article/pii/S0927776506001482 
https://doi.org/10.1016/j.colsurfb.2006.04.014

[19] Tsuruta, T. (2004) Biosorption and Recycling of Gold Using Various Microorganisms. The Journal of General and Applied Microbiology, 50, 221-228.

https://doi.org/10.2323/jgam.50.221

[20] Sakaguchi, T., Nakajima, A. and Tsuruta, T. (1995) Uptake and Recovery of Gold by Immobilized Persimmon Tannin. Proceedings of the XIXth International Mineral Processing Congress, 4, 49-52.

[21] Tsuruta, T. amd Hatano, T. (2015) Removal of Chromium from Chromium(VI) Solutions by Adsorption and Reduction Using Immobilized Persimmon Gel. Journal of Environmental Science and Engineering, 4, 522-531.

http://www.davidpublisher.org/Public/uploads/Contribute/566f70b765cd0.pdf

[22] Nakajima, A. and Baba, Y. (2004) Mechanism of Hexavalent Chromium Adsorption by Persimmon Tannin Gel. Water Research, 38, 2859-2864.

http://www.sciencedirect.com/science/article/pii/S0043135404001800 https://doi.org/10.1016/j.watres.2004.04.005

[23] Aoyama, M., Sugiyama, T., Seki, K., Tuda, M. and Cho, N.S. (1999) Removal of Hexavalent Chromium by Japanese Red Pine Leaves. Journal of the Hokkaido Forest Products Research Institute (Written in Japanese), 13, 15-19.

[24] Ives, D.J.G. (1971) Chemical Thermodynamics. University Chemistry, Macdonald Technical and Scientific, London. 